\title{
Law Enforcement On Notary Engaged Omissions In Minuta Deed Storage Under Act No. 2 Of 2014 Concerning The Position Of Notary
}

\author{
Iin Kamila ${ }^{1}$, Yudhi Atmaja ${ }^{2}$ and Sri Endah Wahyuningsih ${ }^{3}$
}

Abstract. The purpose of this study is to: To identify and analyze the enforcement of the notary negligence on the retention of minutes of the deed by Act No. 2 of 2014 on the post of notary and to identify and analyze any obstacles and solutions in enforcing the law against the notary negligence against minuta deposit certificates based on Act No. 2 of 2014 on the notary office.

The approach used in this paper is empirical sociological juridical with the help of the data used in this study are primary data, secondary data and data that can support tertiary study, which was then analyzed by descriptive analytical method.

Based on the results of this study concluded that enforcement against notary negligence in storage minuta deed is to conduct an inspection after the report is received by the Board of Trustees Territory the Council of Trustees Region held a hearing to examine and take decisions on reports from the public submitted through the Council of Trustees Territory and call the notary's examination of the report. Then the only sanction is the Regional Supervisory Council can impose sanctions only in the form of oral or written reprimand. And the Assembly, Regional Supervisor Council then there could be appeals. And the Regional Supervisory Council can propose sanctions against notris the Central Supervisory Council in the form of a suspension of 3 (three) months to six (6) months and a dishonorable discharge. After the report is forwarded to the Center Supervisor proposes Center on stop sanctioning form with no disrespect to the minister. Dishonorable discharge sanctions are the toughest sanctions levied against the notary who commit violations.

Any obstacles to the enforcement of the notary negligence in storage minutes of the deed of the Majlis Regional Supervisor notary does not have the authority to give a decision on reports from the public, so that people have to wait in a longer time to seek justice for the report, chairman and deputy chairman of the Assembly Supervisors must come from different elements and elected from and by the members of the Supervisory Council. Supervision by the Supervisory Council of Notaries Region Central Java, namely due to time constraints the Supervisory Council members Notary of Central Java region too busy in their respective jobs well as lecturers, notaries and public officials in relevant agencies.

Keywords: Law Enforcement; Negligence Storage; Minuta Deed

\section{Introduction}

Law enforcement is the process of doing the enforcement effort or the functioning of legal norms significantly as a guide in a traffic offender or legal relations in society and state. Law enforcement in concrete terms is a positive legal validity in practice as it should be worth obeying. Hence, justice in a case means the judge in concreto in maintaining and guaranteeing in law material using procedural manner established by formal law.

Notary derived from the word notae, which means secret writing, so it's sort of officials

\footnotetext{
${ }^{1}$ Student of Notary Law, Master Program, UNISSULA Semarang email iinkarmila44@gmail.com

2 Students of Master of Law, Faculty Of Law, Universitas Islam Sultan Agung email yudhiatmaja94@gmail.com

${ }^{3}$ Lecturer of Faculty of Law, UNISSULA Semarang
} 
writer stero. ${ }^{4}$ In daily pengetian notary is a person appointed by the government to create the authentic act or the official deed. Notaries are public officials appointed by the Government to assist the public in making agreements that exist in society. The necessity of written agreements made before a Notary is to ensure legal certainty for the parties to the agreement. The application also the responsibility of the notary in order to preserve and maintain the state archives are well and truly.

Notary is the only public officials who are eligible to create authentic deeds as a perfect proof. $^{5}$ Notary public official shall be positioned as the development Notary not only has the authority but also the administrative liability like a company office. The notary public administration activities can not be separated from the managerial expertise of notaries to perform procedures for archiving. Record keeping notary's office is also part of the administration of the notary. The procedure of the original deposit or certificate along minuta assignment. Notary in Regulation (PJN) in 1860 affirmed that the work of the notary is an official work (ambtelijke verrichtingen) and the only public official authorized to make an authentic deed, as long as there are no regulations that authorize similar to other officials. ${ }^{6}$

In running the Notary office must comply with all the moral code alive and thriving community. Aside from their responsibility and professional ethics, their integrity and morals are essential requirements that must be owned by a Notary Public. In order to carry out their duties properly as a public servant, a professional must run the office by aligning the expertise possessed by upholding professional ethics. In a Notary do profession task must: 1) have a solid moral integrity 2) A Notary must be honest with the client as well as his own (intellectual honesty) 3) Be aware of the limits of their authority. ${ }^{7}$

Against the deed is made, a notary must keep in the collection of documents bound by deed number called minuta deed, while issued to the parties to the deed in the form of a copy of the deed of the exact same sound with certificates stored minuta Notary office. The difference between a certificate with a copy of the minuta deed is located at the end of the deed, the minuta deed there are signatures of the parties and the Notary witnesses, whereas the copies of the deed at the end there is only the signature Notary deed alone.

Notary Deed stored within minutes of Notary deed or protocol, including one state archive documents that must be stored in a long period of time and are kept confidential. Storage deed or / documents stipulated in UUJN-P Article 1 paragraph 13, which reads: "Notary Protocol is a set of documents that come into one's vision on country file should be stored and maintained by the Notary in accordance with the provisions of the legislation".

Notary obligation saving minuta deed stated in Article 16, paragraph (1) letter b Notary Act states that one of the obligations of the notary is "a deed in the form of minutes of the deed and save them as part of the protocol of Notary". "Minuta original deed is the deed that includes the signatures of the penghadap, witnesses and Notary. Minuta deed, book lists and documents supporting this deed deposited as part of the protocol notary ". Expressed in Notary law ${ }^{8}$.

\footnotetext{
${ }^{4}$ Soetarjo Soemoatmojo,1986, Apakah Notaris, PPAT, Pejabat Lelang, Yogyakarta, Liberty, p.4.

${ }^{5}$ Central Board Indonesian Notary Association, 2008, Editor Editor Anke Dwi Saputra, Jati Diri Notaris Indonesia Dulu, Sekarang Dan Dimasa Yang Akan Datang, Jakarta: Gramedia, p. 34.

${ }^{6}$ C.S.T Kansil,et.al., 2003, Pokok-Pokok Etika Profesi Hukum, Jakarta: Pradnya Paramita, p. 87. 7 jurnal.unissula.ac.id/index.php/akta/article/download/2501/1865

8 R. Soegondo Noto Disoerjo, 1993, Hukum Notariat di Indonesia, RajaGrafindo Persada, Jakarta, p. 176.
} 
When minutes of Notary deed is lost or damaged, due to the negligence of Notaries that resulted in losses for people who have the interests of the minuta deed, it can be said Notary heed obligations by UUJN-P charged to him that keep minutes of the deed, minuta deed ensure circumstances must exist. Minuta Deed has the properties to be made one and all to a legal action then there will not be a legal act has two minutes of the deed. The explanation provides a crucial meaning minuta deed that is the only evidence that really what is contained in the deed happens with every description. Notary who lost aktanya as a form of negligence in storing the deed so that damage or even disappear and the destruction of minutes of the deed in his capacity as a notary completeness part of the Protocol.

In UUJN arranged that when Notaries in performing his respective duties proved to have violated, then the notary may be subject or sanctions, sanctions and dismissal warnings either temporarily, with respect, and with disrespect. Based on the background mentioned above, the authors are interested in doing further research to be formulated in the form of research under the title: "Law Enforcement On Notary Engaged Omissions In Minuta Deed Storage Under Act No. 2 of 2014 Concerning The Position Of Notary".

\section{Research methods}

Specification used in this study is a descriptive analysis, which is intended to give the data as accurately as possible about a situation or other symptoms ${ }^{9}$, Because these studies are expected to provide a detailed description, systematic and thorough look at the legislation in force associated with legal theories and practice of positive law.

The data used in this study include: 1) Data Primer, namely legal research sources can be divided into research sources in the form of primary legal materials and secondary law. Primary legal materials consist of legislation and other relevant regulations, official records or minutes in making legislation. While the secondary material in the form of all publications on the law which is not an official documents. Publication of the law include text books, dictionaries of law and legal journals: ${ }^{10}$

2) The secondary data, that is data obtained directly in the field, but rather obtained from the study of literature books, records, documents, laws and regulations, the results of scientific research and sources other literature relating to the cases which in research. Secondary data includes a) Primary Legal Materials which are: The Book of Civil Law; Act No. 30 of 2004 concerning Notary; Act No. 2 of 2014 on the amendment of Act No. 30 of 2904 concerning Notary; b) Legal Materials Secondary legal materials of secondary materials are closely related to the primary legal materials and can help to analyze and understand the primary legal materials include: books about the code of ethics, book of the notary, the Internet, and books on research methodology, Scholars scientific results about the role of the Notary. c) Tertiary Legal Materials, tertiary legal materials are materials that provide information about the primary legal materials and secondary law, which consists of: Law Dictionary, dictionaries other related fields of study of this research.

\section{Results and Discussion}

\subsection{Law Enforcement On Notary Engaged Omissions In Minuta Deed Storage Under Act No. 2 of 2014 Concerning The Position Of Notary}

\footnotetext{
${ }^{9}$ Soerjono Soekanto \& Sri Mamuji, 2001, Penelitian Hukum Normatif suatu tinjauan singkat Jakarta:RajaGrafindo Persada, p 43

${ }^{10}$ Peter Mahmud Marzuki, 2006, Penelitian Hukum, akarta:Kencana Prenada Media Group, p.93
} 
Law enforcement is a process for realizing the laws desires into reality. The so-called law of desire here is nothing but the thoughts of law-making bodies as defined in the rule of law. The legal regulations. Formulation legislator thinking as outlined in the legislation will also determine how the law enforcement run. ${ }^{11}$

According to the results of an interview with Mr. Danang, SH., Secretary of the MPW Central Java on May 24, 2019, ${ }^{12}$ Administratively, the instrument of law enforcement in Notary law if their offense for notaries negligence in storage minuta deed or also called as part of the protocol notary concerning their public statements concerning negligence by Notaries are detrimental to society then the Tribunal Regional Supervising directly process the report, concerning reports from the public regarding the alleged negligence by Notaries are detrimental to society, then the Regional Supervisory Council should also hold a session by calling the complainant (the public) and reported (Notary reported). So it will get a clear explanation of the problems that occurred that will ultimately determine the decisions based on these assessments. But if in the process undertaken by the Regional Supervisory Council if the calling area is not present Supervisory Council, then submitted to the Supervisory Council of the Territory.

Mechanisms or procedures for such reporting contained in the Regulation of the Minister of Justice and Human Rights of the Republic of Indonesia Number: M.02.PR.08.10 2004 on Procedures for the Appointment of Members, Termination, Organizational Structure Working Procedures, Inspection Procedures and Notary Supervisory Council Submission of Reports Second part of Article 21 states that:

\subsubsection{Submission of Reports}

- Reports can be filed by parties who feel aggrieved.

- They must be submitted in writing in the Indonesian language accompanied by evidence of which can be accounted for.

- Reports about the alleged violation or breach Notary Code implementation Notary office submitted to the Regional Supervisory Council.

- Public statements other than those referred to in paragraph (3) shall be submitted to the Supervisory Council of the Territory.

- In the event that the report referred to in paragraph (3) shall be submitted to the Regional Supervisory Council, the Regional Supervisory Council will forward to the Assembly Regional Supervising authorities.

- In the event that the report referred to in paragraph (3) shall be submitted to the Central Supervisory Council, the Supervisory Council forwarded it to the Assembly Center Regional Supervising authorities.

Those who feel aggrieved can report to the Regional Supervisory Council in the city of Semarang. After submission of the report will be made to the call according denan Article 22. Here is the mechanism in the call:

\subsubsection{Dialing}

- Examining Assembly Speaker shall summon to the reporting and reported.

- Dialing is done by mail by the secretary no later than five (5) business days prior to the hearing.

- In urgent situations calling as referred to in paragraph (2) can be done by fax immediately followed by summons.

- In the case reported having been summoned legally and worthy, but not present

${ }^{11}$ Satjipto Raharjo, 2009, Penegakan Hukum Sebagai Tinjauan Sosiologis, Genta Publishing, Yogyakarta, p. 25

${ }^{12}$ According to the results of an interview with Mr. Danang, SH., Secretary of the MPW Central Java on May 24, 2019 
then conducted a second summons.

- In the case reported having been summoned legally and worth a second time but still did not attend the inspection was carried out and the decision is made without the presence of the reported.

- in the case of the complainant having been summoned legally and should not present, then the second summons, and if the complainant remains absent then the Assembly Audit report states fall and can not be filed again.

On initial inspection report will be handled by the Regional Supervisory Council notary as the domicile of the notary as for inspection by the Regional Supervisory Council contained in the Regulation of the Minister of Justice and Human Rights of the Republic of Indonesia Number M.02.PR.08.10 2004 Article 23 and Article 24 states that :

\subsubsection{Examination by the Supervisory Council of Regions}

- Examination by the Council of Regions Examining closed to the public.

- Inspection begins within a period of at least 7 (seven) calendar days after receipt of the report.

- Regional Audit Council will have completed the examination and submit the results of the examination within a period of at least 30 (thirty) calendar days since received. Result inspection report referred to in paragraph (3) shall be recorded in the official report signed by the chairman and secretary.

- The cover letter delivery investigation report submitted to the Regional Supervisory Council forwarded to the complainant, reported, the Supervisory Council of the Center, and the Association of Regional Indonesian Notary.

Once the report is received by the Supervisory Council of the Assembly of Trustees Region Region held hearings to examine and take decisions on reports from the public submitted through the Regional Supervisory Council and calling the notary's examination of the report. Then the only sanction is the Regional Supervisory Council can impose sanctions only in the form of oral or written reprimand. And the Assembly, Regional Supervisor decided then there could be appeals. And the Regional Supervisory Council can propose sanctions against notris the Central Supervisory Council in the form of a suspension of 3 (three) months to six (6) months and a dishonorable discharge.

After the report is forwarded to the Center Supervisor proposes Center stop sanctioning form with no disrespect to the minister. Dishonorable discharge sanctions are the toughest sanctions levied against the notary who violates the code of ethics and Notary law.

According to the results of an interview with Mr. Muhammad Hafid, SH,. MK.n as chairman of the Regional Committee Semarang Indonesian Notary Association ${ }^{13}$ it is the responsibility of each for notary negligence in minuta deed storage. And may be the reason for the parties who suffered losses to demand reimbursement of expenses, damages and interest to the notary.

Those who feel aggrieved can report to the Regional Supervisory Council in the city of Semarang. After submission of the report will be made to a calling, On preliminary examination report will be handled by the Board of Trustees of Regional notary as the domicile of the notary as for examination by the Assembly Regional Supervisor, At the first hearing specified, the reporting and reported is present, then the Assembly Examiner Regions examination by reading reports and heard the testimony of the

${ }^{13}$ The interview with Mr. Muhammad Hafid, SH ,. MK.n as chairman of the Regional Committee Semarang Indonesian Notary Association 
complainant. In the examination referred to in paragraph (1) Reported were given ample opportunity to submit a response. Rapporteur and reported to present evidence to support the arguments put forward. Examiner reports are examined by the Regional Assembly at the latest within a period of 30 (thirty) calendar days after receipt of the report.

As for the sanctions to notaries who commit an offense can be divided into three (3) aspects:

- Aspects of civil liability, namely the replacement costs, damages or interest may be charged against the notary must be based on a legal relationship between the parties notary facing notaries.

- Aspects of the administrative responsibilities that the Supervisory Council take preventive measures, to enforce compliance, to apply sanctions reprensif and separately impose sanctions compliance that can be implemented. Administrative sanctions oral reprimand, written reprimand, suspension, dismissal with respect, dishonorable discharge.

According to the author analyzes if associated with law enforcement theory by Satjipto Rahardjo ${ }^{14}$ Law enforcement is a process to realize the desires of the law (ie thoughts lawmaking bodies formulated in legal regulations) became a reality. In law enforcement against negligence in storage notary minuta deed then be given the following sanctions:

- verbal warning

- written warning

- lay-off

- Honorable discharge

- Dishonorable discharge

If the Notaries do that instead of deliberate but, because of negligence or because of their force majeure, Received no sanction because, despite his will. Negligence in question can be due to lack of prudence in storing minuta deed that causes the minuta deed not know they exist or may also be brought by the employee by reason of resentment against the Notary. Other omissions are for their office move that led to the minuta deed scattered, because of the negligence of the received sanctions Notary is not too heavy because it is not intent to eliminate the minuta deed.

Factor force majeureie events that can not be estimated as examples of natural disasters. With the natural disasters that cause minuta certificate is missing, it Notaries can not be held responsible for negligence and deliberate outside the Notary. Yet for the Notary deed does not make or keep minutes of the deed is intentional factor, as clearly stipulated in Article 16 paragraph (1) letter b Act No. 02 of 2014 that the minutes of the deed must be created and saved as a Notary protocol.

\subsection{Obstacles and solutions In Law Enforcement On Notary Engaged Omissions In Minuta Deed Storage Under Act No. 2 of 2014 Concerning The Position Of Notary}

According to the results of an interview with Mr. Danang, SH., Secretary of the MPW (Regional Supervisory Council) Central Java on May 24, 2019. ${ }^{15}$ The existence of obstacles to the enforcement of the notary negligence in minuta deed storage based on Act No. 2 of 2014 on notaries office as follows:

\footnotetext{
${ }^{14}$ Satjipto Rahardjo, Loc. Cit

${ }^{15}$ Interview with Mr. Danang, SH., Secretary of the MPW Central Java on May 24, 2019
} 
- Regional Supervisory Council of the notary does not have the authority to give a decision on reports from the public, so that people have to wait in a longer time to seek justice for the report

- The restrictions on a very short time from the start of receipt of the report until completing the examination with a notary supervisory board members consisting of three (3) representatives of the government, notary organizations, and academic experts. Chairman and deputy chairman of the Supervisory Council must come from different elements and elected from and by the members of the Supervisory Council. Supervision by the Board of Trustees Territory Notary Central Java, namely due to time constraints Assembly members Supervisory Territory Notary Central Java are too busy in their respective jobs well as lecturers, notaries and public officials in relevant agencies, the lack of communication between members in the House of Trustees Territory notary Central Java in carrying out oversight functions.

- Less widespread public knowledge of the proceedings in the reporting of losses on alleged violations committed by a notary.

The solution solution that can be given by the Board of Trustees Region namely:

- Due to the Regional Supervisory Council had no authority to give a decision on the report the Regional Supervisory Council is required as soon as possible to prepare minutes and immediately sent to the Regional Supervisory Council to immediately be in the process.

- Creating and immediately set up a schedule to three (3) elements of the Supervisory Council members who have slack time and when there is time to be immediately scheduled to conduct the examination.

- Disseminating information and appeal to the people of the Supervisory Council of Regions, Regional Supervisory Council, the Ministry of Justice and Human Rights and legal counseling

According to the analysis the authors found to overcome the obstacles in the implementation of the supervision of a notary, that the Supervisory Council members should not give time to discuss the vision for the future in order better to perform supervisory duties. Because it is the duty and responsibility of those who are willing to have a member of the Supervisory Council, and has become the consequences for them as members of the Supervisory Council.

According to the results of an interview with Mr. Danang, SH., Secretary of the MPW Central Java on May 24, 2019, explained that Up to now there has been in the region of Central Java has been no reporting notary minuta deed negligent in storage. If there is reporting on notaries were negligent in the minutes of the procedure and storage procedures and sanctions have clearly stipulated in Act No. 2 of 2014 regarding the amendment of Act No. 30 of 2004 On Notary. ${ }^{16}$

\section{Closing}

\subsection{Conclusion}

- Law enforcement against notary negligence in storage minuta deed by Act No. 2 of 2014 on the post of notaries to conduct an inspection after the report is received by the Board of Trustees Territory the Council of Trustees Region held a hearing to examine and take decisions on reports from the public submitted through the Regional Supervisory Council and calling the notary's examination of the report.

${ }^{16}$ Interview with Mr. Danang, SH., Secretary of the MPW Central Java on May 24, 2019 
Then the only sanction is the Regional Supervisory Council can impose sanctions only in the form of oral or written reprimand. And the Assembly, Regional Supervisor Decided then there could be appeals. And the Regional Supervisory Council can propose sanctions against notris the Central Supervisory Council in the form of a suspension of 3 (three) months to six (6) months and a dishonorable discharge. After the report is forwarded to the Center Supervisor proposes Center pemberhentin sanctioning form with no disrespect to the minister. Dishonorable discharge sanctions are the toughest sanctions levied against the notary who commit violations.

- Barriers and enforcement solutions to the notary for negligence in storage minuta deed by Act No. 2 of 2014 on the post of notaries that the Assembly Regional Supervisor notary does not have the authority to give a decision on reports from the public, so that people have to wait for much longer to seek justice for the report, chairman and deputy chairman of the Supervisory Council must come from different elements and elected from and by the members of the Supervisory Council. Supervision by the Supervisory Council of Notaries Region Central Java, namely due to time constraints the Supervisory Council members Notary Central Java region too busy in their respective jobs well as lecturers, notaries and public officials in relevant agencies.

\subsection{Suggestion}

- UUJN not regulate how the procedure and manner minuta deed storage and also does not regulate how the responsibilities of a notary public for the loss, destroyed or lost minutes of certificates that are in storage. Therefore Society does not have certainty and legal protections for their losses due to violations of the notary of the provisions of Article 16, paragraph (1) b and i, as should the notary save minuta deed as part of the protocol notary in a state that is safe and appropriate like a letter valuable. UUJN supposed to set about it.

- In the face of obstacles by providing a specially to perform supervisory duties, the need for regular meetings every quarter to discuss the performance of each member of the Council of Trustees Notary Regional Assembly and Regional Supervisor, discuss the violations of Notary if there are reports from the public, and discuss work program for 1 (one) year as well as an evaluation of each meeting.

\section{Bibliography}

[1] Soetarjo Soemoatmojo, 1986, Apakah Notaris, PPAT, Pejabat Lelang, , Liberty, Yogyakarta

[2] Pengurus Pusat Ikatan Notaris Indonesia, 2008, Editor Anke Dwi Saputra, Jati Diri Notaris Indonesia Dulu, Sekarang Dan Dimasa Yang Akan Datang, Jakarta.

[3] C.S.T. Kansil, et. al., 2003, Pokok-Pokok Etika Profesi Hukum, Pradnya Paramita, Jakarta

[4] R. Soegondo Notodisoerjo, 1993, Hukum Notariat di Indonesia, RajaGrafindo Persada, Jakarta

[5] Soerjono Soekanto dan Sri Mamudji, 2011, Penelitian Hukum Normatif Suatu Tinjauan Singkat, ed 1, Cet. ke-13, Raja Grafindo Persada, Jakarta

[6] Peter Mahmud Marzuki, 2006, Penelitian Hukum, Kencana Prenada Media Group, Jakarta

[7] jurnal.unissula.ac.id/index.php/akta/article/download/2501/1865 